\title{
Notes on Extended Uses of pues in Basque Country Spanish*
}

\author{
Bruno Camus Bergareche \\ University of Castilla-La Mancha \\ Bruno.Camus@uclm.es
}

Received: $16-12-2017$

Accepted: 07-11-2020

Published: $15-12-2020$

How to cite: Camus, Bruno. 2020. Notes on Extended Uses of pues in Basque Country Spanish. Isogloss. Open Journal of Romance Linguistics 6, 9: 1-19.

DOI: https://doi.org/10.5565/rev/isogloss.64

\begin{abstract}
This work is intended to present a preliminary approach to some of the facts related to the Basque Country Spanish extended use of the connective pues 'so, therefore, consequently...'. The differences between the Standard Spanish pues and the Basque uses of this same particle will be examined and thoroughly described in order to establish the distinctive syntactic and semantic features of the latter. By so doing, we will introduce the topic of a possible language contact explanation. In this regard it will be necessary to face similar facts about pues in Andean Spanish in contact wtih Quechua. This complete scenario of coinciding developments for pues in Spanish

This research is part of the project "El español en contacto con otras lenguas II: variación y cambio lingüístico" headed by Azucena Palacios (Universidad Autónoma de Madrid) and partly funded by the Spanish Ministerio de Economía y Competitividad (Ref. FFI2015-67034-P). We would like to thank the three anonymous reviewers for their helpful comments and their contribution to improve this work. Any errors are solely ours.
\end{abstract}


contact dialects will be finally taken into account in order to suggest some of the paths leading to an explanation of the origins of the specific uses of pues in Basque Country Spanish.

Keywords: connectives; contact Spanish; Basque Country Spanish; Andean Spanish; language convergence.

\section{Table of Contents}

\author{
1. Introduction \\ 2. Pues in Contemporary \\ Peninsular Spanish \\ 3. Pues in Basque Country Spanish
}

4. Final remarks: exploring the origins of BCS pues

5. Concluding remarks

References

\section{Introduction}

In the variety of Spanish spoken in the Basque Country (Basque Country Spanish, BCS henceforth, Camus \& Gómez Seibane 2012: 6-7), the discourse marker pues 'because; well; so, therefore, consequently...' of Standard Peninsular Spanish, regularly in sentence initial position, shows some distinctive uses as a connective adverb in sentence final position. Some of the relevant data are shown in the following sentences ${ }^{1}$ :

a. $\quad-¿$ Y aónde vais a ir hoy, pues..., a la tarde?

'- And where are you going then..., in the afternoon?'

(COSER, Luzuriaga AL-0107: 60)

b. Sí, es que ya te digo, pues; mis hermanos estuvieron en guerra cinco meses...

'Yes, I'm telling you in that case; my brothers remained at war five months...'

(COSER, Leitza NA-3214: 13)

The first sentence (1a) is uttered by a monolingual Spanish speaker and the second one (1b) by a bilingual speaker with Basque as first language but good proficiency in Spanish. Both examples show a similar pattern for pues: a stressed word in clause-final position, followed by a clearly audible pause marked by comma or semicolon.

The examples come from the surveys of COSER (Corpus Oral y Sonoro del Español Rural) corresponding to the Basque provinces. As explained in its website, this database is a collection of oral tokens from rural surroundings. They are identified in the examples by a code indicating the province, town and the page of the corresponding transcription. I want to thank Inés Fernández Ordóñez, Carlota de Benito and Olga León for the access to these unpublished materials of COSER in the Basque Country. Without their kind and excellent disposition this work would not have been possible. 
As we shall explain in section 2, pues, when functioning as a connective word in Standard Peninsular Spanish, shows a different behaviour. It is an unstressed word leaning on the following stressed form and placed mainly in clause-initial position. The following sentence (2) illustrates this standard usage: pues is placed at the beginning of the sentence and must be pronounced in the same stress group as the following word yo, a stressed pronoun:

(2) ¿No se ha enterado de que el lenguaje nos habla? Pues yo sí

'Don't you know that language talks to us all? Well, I do'

(J. A. Marina, Ética para náufragos, 33, in Portolés 2001: 55, ex. 17)

The specificity of the Basque usage shown in (1) is recognised and abundantly mentioned by current grammarians or databases such as ASinEs (Atlas Sintáctico del Español). Its most salient features are also carefully noticed. One of the first works dedicated to the connective pues recalls that

"en algunas zonas del norte peninsular [...] la reiteración de su uso, su colocación [of pues] al final del enunciado no es la más habitual..."2 (Portolés 1989: 126).

Recently, Portolés (2016: 697) advises that

"también el estudio del contacto de lenguas puede explicar usos dialectales de marcadores discursivos. Distintos usos de pues serían un ejemplo tanto para América - contacto con lenguas indoamericanas- como para España — contacto con el vasco—"3.

And, most significantly, the academic grammar clearly reports this divergent Basque use:

“...en el País Vasco (España), [pues] se emplea al final de muchos enunciados como recurso enfático (¿Vienes a la playa, pues?) no siempre relacionado con el discurso precedente" ${ }^{\text {(RAE-ASALE 2009: } § ~ 30.13 m) . ~}$

As shown, these works draw attention on some relevant trends partially exemplified by the sentences in (1): a) the sentence final position of pues, b) its location in an area around the Basque Country, c) its possible connection with Basque language and the relationship with similar strategies for pues in American Spanish.

2 'In some areas of Northern Spain [...] the repetition of its use, its sentence final distribution [of pues] is not at all regular'.

3 'The study of languages in contact can also explain dialect uses of discourse markers. Different uses of pues would be a good example both for America contact with indigenous languages - and for Spain — contact with Basque - '. "...in the Basque Country (Spain), [pues] is used at the end of many sentences as an emphatic resource (¿Vienes a la playa, pues?) that cannot always be related to the preceding discourse". 
This work is aimed to present a preliminary approach to some of the facts related to this Basque use of pues. Firstly we will determine the differences between the Standard Spanish pues and the BCS extended uses of this same particle as seen in (1). Section 2, as already mentioned, will describe the different meanings of Standard Spanish pues and their classification and category. We will focus specifically on pues as a discourse marker or connective and its two variants, the commentating use and the consecutive use. Section 3 will be devoted to describe the local and distinctive uses of pues in BCS and its specific syntactic and semantic features. We will defend a basic semantic connection with consecutive connectives in Standard Spanish, that is, entonces 'so, then' and consecutive pues. It will also be shown that BCS pues belongs to a more colloquial and informal register than Standard Spanish consecutive pues and presents a higher frequency that can be explained as an extension of this original consecutive meaning.

The following section, 4, will be dedicated to place this extended use of pues in a more general context. First of all, it will be necessary to attend to the relation of this BCS use of pues to similar pieces in Basque language. In so doing, we will introduce the topic of a possible language contact explanation. In this regard, it will be also necessary to face similar facts about pues in American Spanish varieties and, more specifically, in Andean Spanish in contact wtih Quechua. This complete scenario of coinciding developments for pues in Spanish contact dialects will be finally considered as a plausible starting point for future explanatory hypothesis.

\section{Pues in Contemporary Peninsular Spanish}

During the last thirty years, Spanish grammarians and specialists in Colloquial Spanish and discourse markers have thoroughly examined connective particles in this language, so that previous literature on Peninsular Spanish pues and its different uses is abundant. In this section, we will follow the main claims made in these works about this particle. A general account on pues is provided in different works by Portolés $(1989,1993,2001: \S 3.4$ y $\S 8.2)$ and they will be our guide in the following description of contemporary uses in Peninsular Spanish. The works by Dorta Luis - Domínguez García (2001) and Fuentes (2009: s.v. pues ${ }^{l}$ - pues $^{6}$ ) will be taken into consideration regarding the phonetic features of pues and some of its pragmatic values. Finally, it will be necessary to mention the general overview offered by the academic grammar on pues and its different types (RAE ASALE 2009: $\S 30.13$ y $\S 46.12$ ). Before we present these previous descriptions in detail, we will again insist on the existence of two basic classifications for pues in Spanish. In the first place, there is a conjunction pues that conjoins the two members of a compound sentence. And there is also a discourse marker pues with two main semantic and pragmatic values: the so-called commentating pues and consecutive pues. We will, first of all, consider the conjunctional pues and the connective uses of this word, both of them relevant to the discussion of BCS pues. 


\subsection{Pues as a causal conjunction}

The first use of pues mentioned above, as a conjunction of causal meaning, is nowadays almost forgotten in the spoken language (Garcés 1992: 271). As a conjunction, it serves as a nexus between two clauses in a compound sentence. It is related to the ancient phrase pues que 'because' and ultimately to the Latin temporal particle POST QUAM (Herrero Ruiz de Loizaga 1998). The following sentences in (3) illustrate this use of the so-called causal pues:

(3) a. El autobús no llega, pues hay un formidable atasco.

'The bus doesn't arrive because there is a huge traffic jam'

b. Existo, pues pienso.

'I am because I think'

As seen in (3), the clause introduced by pues follows the clause that contains the conclusion connected with the argument presented in the pues clause. This final position for the pues clause is mandatory. That is, contrary to other causal clauses in Spanish such as porque clauses in (4), pues clauses cannot be fronted, as shown in (4):

$$
\begin{aligned}
& \text { a. Existo porque pienso. } \\
& \text { 'I exist because I think' } \\
& \text { b. Porque pienso, existo. } \\
& \text { 'Since I think, I exist' }
\end{aligned}
$$

(5) a. Existo, pues pienso.

b. *Pues pienso, existo.

Portolés (1989: 121-123) distinguishes this interpretation of pues in Spanish from the one found in standard causal subordinating conjunctions such as porque 'because'. As this author points out, the clause introduced by causal pues must be understood as an argument in favour of the preceding clause. And crucially, this preceding clause should then be interpreted as corresponding to the speaker's statement. Thus, examples in (3) can be paraphrased as the following:

(6) a. (Porque/como) hay un formidable atasco, puedo decir que el autobús no llega.

'(Because/as) there is a huge traffic jam, I can say that the bus won't arrive'

b. (Porque/como) pienso, puedo decir que existo.

'(Because/as) I think, I can say that I exist'

To conclude, causal pues in Spanish is a conjunction that introduces a clause referring to the speaker's statement in the preceding clause. Thus it differs from less restricted causal conjunctions such as porque 'because', which can also lead to an interpretation of its clause as the expression of the cause of what is said, that is, the statement. 


\subsection{Pues as a discourse marker}

Contrary to what has been explained before about causal pues, the uses of pues as discourse marker cannot join together the two members of a compound sentence. On the contrary, pues as discourse marker in Spanish introduces independent sentences or is placed inside of them. That is why it is considered as an adverbial form, a continuation of the Latin temporal adverb POST. This pues is also commonly described as a connective particle because it contributes to the cohesion of a discourse by establishing semantic and pragmatic connections among its parts (Portolés 1989). As a discourse marker, pues corresponds to two different syntactic distributions. The first one - as in (2) above, repeated as (7) below - is what Portolés (2001: 55) calls pues comentador 'commentator pues, commentating pues', usually placed sentence initially:

¿No se ha enterado de que el lenguaje nos habla? Pues yo sí

'Don't you know that language talks to us all? Well, I do'

(J. A. Marina, Ética para náufragos, 33, in Portolés 2001: 55, ex. 17)

There is, nonetheless, another type for connective pues in Spanish. This so-called pues consecutivo 'consecutive pues' is usually placed inside the clause, as shown in the following sentence:

(8) Tú cometiste la culpa: sufre, pues, la pena (Gramática RAE).

'You committed the offence: suffer, therefore, the punishment'

(Portolés 1989: ex. 3)

The following sections will be devoted to the description of these two different types of connective pues in Spanish.

\subsubsection{Pues as a commentating connective}

The commentating connective pues is used to present a different or new comment, remark or description that is added to previous considerations (Martín Zorraquino \& Portolés 1999: § 63.2.2.1; Portolés 2001: 137-138; Portolés 2016: 693-694). It generally corresponds to the connective use of the English particle well or 'cos (Stenström 2006a, 2006b). Other Spanish connectives also play a similar semantic and pragmatic role. Among them, the following particles can be listed: así las cosas 'this being so', bien 'well', dicho eso 'that said, having said that', pues bien 'well, well then'. In addition to the previous example in (7), the next sentences also illustrate this use of commentating pues in Spanish:

a. $\quad-i$ Y eso en qué consiste?

- ¿El proyecto? Pues nada, por ejemplo, te dan unas bases sobre un aula o sobre determinado colegio...

'- And what is that?

- The project? Well, nothing, for instance, they give you the standards for a classroom or for a specific school...'

(Val.Es.Co. 2.0, conversación 0001, 0008-00095) 
b. - ¡Odio el CEU San Pablo!

- $(\ldots)$

- Desde que tenía cuatro años.

- ¿Pues tú no querías estudiar Periodismo en el CEU?

- I hate CEU San Pablo!

- (...)

- Since I was four.

- So ¿didn't you want to study Journalism at CEU?'

(Val.Es.Co. 2.0, conversación 0008, 0025-0028)

In examples (7) and (9), pues introduces new information related to the previous data already provided on a given topic, either by the same speaker (7) or by another participant (9). By so doing, the pues sentence contributes to the progress of the conversation with relevant comments of various kinds.

As the source of these examples indicates, this pues belongs to an informal spoken or colloquial register and is abundantly found in conversational Spanish. It is an unstressed particle that needs to lean on some contiguous stressed word, a feature that complicates its classification as a proper adverb (Portolés 2001: 5556). As shown in (7) and (9), it is most commonly placed sentence initially, and therefore it is defined by a previous pause. As the examples show, this pause corresponds orthographically to any of the first order punctuation marks such as a semicolon or a full stop. However, commentating pues can occasionally be found inside the clause (Fuentes 2009: s.v. pues $^{2}$ and pues $^{5}$; Olbertz 2013: 181):

(10) a. ...y la verdad, ya queremos que alguien realmente pues nos saque adelante...

'....and the truth is, we want really someone to, well, provide for us'

(Fuentes 2009: s.v. pues $^{2}$ )

b. $\quad . .$. sin embargo en este barrio/ pues no hay tanto/ ahora mismo/ ha habido hace una temporada ha habido// hubo también bastante:/ al lado/...

'...but in this neighbourhood, well, there isn't that much at this moment, there has been some time ago, there has been, there was much here next door...'

(PRESEEA, Alcalá de Henares, instrucción primaria, encuesta $39^{6}$, in Olbertz 2013: ex. 3)

Even though it is not always clear from the transcription, this distribution of pues in these examples is not essentially different from the general pattern of (9). In the two sentences of (10) pues is also preceded by a pause and must be uttered in this way to be properly understood.

actual spoken conversations on different topics mainly from the city of Valencia in Spain.

6 This example from Olbertz (2013) comes from the surveys of PRESEEA

(Proyecto para el Estudio Sociolingüístico del Español de España y América

'Project for the Sociolinguistic Study of Spanish from Spain and America'), a corpus of transcriptions of Contemporary Spoken Spanish from different European and American Spanish speaking cities. 
The aforementioned specific stylistic, distributional and accentual features of this pues set it clearly apart from the causal pues described in section 2.1. But still the main difference lies in semantics. As Portolés (2009: 137-138) described, in sentences (7) and (9) pues introduces new information related to the previous data already provided on a given topic, either by the same speaker (7) or by another participant (9). By so doing, the pues sentence contributes to the progress of the conversation with relevant comments of various kinds. Unsurprisingly then this pues is classified as a discourse-ordering particle by Spanish grammarians. Even more, some works consider pues as a continuative connective in the sense that it would serve to order a series of different comments as a continuation of a preceding one (Portolés 1989: 129-133; Fuentes 2009: s.v. pues ${ }^{2}-$ pues $^{6}$; DPDE: s.v. pues ${ }^{1}$; Olbertz 2013).

The same continuative function is considered in other works. They generally underline the weak connection established by this pues, therefore defined as a simple illative connective (RAE - ASALE 2009: $\S 46.12 \mathrm{~m}$-s; Fuentes 2009: s.v. pues $^{3}$, pues ${ }^{4}$, pues ${ }^{6}$ ). As other illative particles, it would simply establish a general logical relation with what is previously said and provides cohesiveness to the whole conversation or discourse.

\subsubsection{Pues as a consecutive adverb}

The remaining use of pues as a discourse marker in Peninsular Standard Spanish, a consecutive adverb, belongs again to a written and formal register, as was the case for the causal pues. As Portolés (2001: 55) states, this pues corresponds to a stressed form and is placed between pauses (commas, semicolons or full stops in the orthographic transcriptions) inside the clause, as we previously showed in (8), here repeated as (11):

(11) Tú cometiste la culpa: sufre, pues, la pena (Gramática RAE).

'You committed the offence: suffer, therefore, the punishment'

(Portolés 1989: ex. 3)

Only when the relevant sentence is short, for instance in orders and with imperatives, can this consecutive pues appear at the end of the sentence:

Levántate, pues.

'So wake up then'

(Quintero, E., Danza, in RAE - ASALE 2009: § 46.12m)

This adverb is needed to introduce a consequence or a result of the facts that were described in a previous clause, as seen in (11). Thus, it is more or less synonymous with other consecutive connectives such as así pues, en consecuencia, por tanto, entonces ('therefore, consequently...') But there are, nevertheless, some differences between consecutive pues and consecutive entonces. First of all, the adverb entonces belongs to an informal register in Peninsular Spanish, whereas consecutive pues is found only in written and formal styles. But, more interestingly, consecutive pues has a wider range of uses than entonces (Portolés 1989: 128-129). Pues can be placed inside a sentence of consecutive meaning that belongs to the same (13a) or a different person (13b) 
from that of the previous one, as shown in the following contrasting pair of examples:

(13) a. Estoy cansado. Me voy, pues, a la cama.

'I'm tired. So I'm going to bed'

b. - Estoy cansado. - Vete, pues, a la cama.

'- I'm tired. - So go to bed'

On the contrary, entonces is only possible as a reply to an intervention by another participant, as in (14b):

(14) a. ??Estoy cansado. Me voy, entonces, a la cama.

'I'm tired. So I'm going to bed'

b. - Estoy cansado. - Vete, entonces, a la cama.

'- I'm tired. - So go to bed'

As we have just seen, this consecutive pues, used as a discourse marker or connective, presents some important differences concerning register, distribution, stress, meaning and pragmatic function with respect to the previously described commentating pues and therefore deserves special attention.

To summarize, we will now recall the main features distinguishing these two connective uses of pues and also those of the previous causal pues in Contemporary Peninsular Spanish. First, pues can be a causal conjunction only found in written and formal language nowadays. As a conjunction it serves as a nexus between two clauses in a compound sentence. This conjunction pues always introduces the second member of the compound sentence. Differently from other Spanish causal clauses, the causal pues clause can never be moved to the front of the whole sentence that contains it. It also has a more restricted interpretation than the general Spanish causal conjunction porque. Pues can only introduce a clause that must be interpreted as an explanation referring to the speaker's statement in the preceding clause.

Besides this conjunctional use, pues can also be a discourse marker. In this case it presents two different distributions, each corresponding to different registers. In the first place pues has a general distribution in Spoken or Colloquial Spanish that we have called commentating pues, following Portolés (2001). In this use, pues is an unstressed particle phonetically attached to the following contiguous stressed word. It is limited by a previous pause of some duration and thus it generally introduces its clause. This pues introduces new information related to the previous data already provided to a given topic, either by the same speaker or by another participant. The link with the previous statements is often weak and pues is commonly intended just to provide some continuity to the whole discourse.

Finally, pues as a discourse marker can also be found in formal and written Spanish as a consecutive adverb. In this case it is generally placed inside the clause. Differently from commentating pues, it is a stressed form commonly limited by pauses. Its presence forces its clause to be interpreted as a consequence or a result of the facts that were described in a previous clause. This previous clause may refer to the same speaker or a different one than the clause with pues. 


\section{Pues in Basque Country Spanish (BCS)}

\subsection{The Standard uses of Peninsular Spanish pues in the Basque Country}

Before we address the description of divergent uses of pues in BCS, it is important to notice that these coexist together with standard uses of pues. The colloquial commentating pues, described in section 2.2.1. above, is regularly documented in the corpora of current spoken language, such as COSER or CorpusPV:

(15) a. Hasta las 6 y media que salgo, unos días, otros días, pues al final se sigue alargando la jornada laboral hasta las $7 \ldots$

'Until I go out at half past six some days, well, other days the workday is extended until seven o'clock...'

(CorpusPV, Jokiñe, Llodio: 1)

b. cuanto más viejunas estén así como más maceradas, bueno, pues muchísimo mejor...

'the older they are, that is, the more marinated, well, the better...'

(CorpusPV, programa ETB Robin Food 3 18/01/2016:

minutos 01:04-01:10).

c. $\quad$ - Y, ¿para qué usaban las morcillas?

- Pues pa repartir, y pa casa también...

'- And what did you use black sausages for?

- Well, to distribute them, and also for the family...'

(COSER, Leitza NA-3214: 3)

These three examples correspond to actual conversations and belong to Basque speakers of different linguistic background. Examples (15a-b) are from native Spanish speakers with some knowledge of Basque as a second language; the first one is from a Spanish speaking area and the second one from a Basque speaking area. (15c) instead corresponds to a native speaker of Basque with Spanish as a second language and from a Basque speaking area. They use commentating pues as shown in (7) and (9-10) above, that is, as any other Peninsular Spanish speaker. We find this pues giving continuity to a discourse by the same person in (15a-b) or in a reply by another participant in a conversation in (15c). The three examples show an unstressed pues phonetically attached to the following words and preceded by a short pause in (15a-b) or introducing a new sentence in $(15 \mathrm{c})$. All of them illustrate how the pues clause introduces new contents that complete the discourse and make it progress.

This corpus is still in progress and will be available online in the site Español en contacto con otras lenguas: Variación y cambio lingüístico (http://espanolcontacto.fe.uam.es/wordpress/). It includes at the moment some fifteen hours with samples of spoken Spanish from semi-structured interviews with young urban men and women and fragments of informal and spontaneous dialogues from Basque television ETB shows. People involved in these shows comprise different ages and mono- and bilingual speakers of rural or urban areas from the Basque Autonomous Community and Navarre. 
The uses of pues found in formal Standard Spanish, that is the causal pues of section 2.1 and the consecutive pues of section 2.2.2, are also regularly found, for instance, in the modern literature of Basque writers, such as multi-awarded author Fernando Aramburu. The following examples come from his last novel and illustrate a causal pues (16a) and a consecutive pues (16b):

a. $\quad$...Ikatza debió de notarlo, pues se despertó alarmada.

'...Ikatza should have realised it because she woke up alarmed'

(Patria: 491)

b. Y recordó una maxima del instructor: no asesinamos, ejecutamos. Mucho cuidado, pues, con fallar.

'And he remembered a saying by the instructor: we don't murder, we execute. Be very careful then not to fail'

(Patria: 273)

Both the sentences in (16) make part of the narrator's comments in the novel and therefore correspond to a literary register. In (16a) pues introduces as a conjunction the second member of a causal compound sentence. This pues clause corresponds to an explanation for the behaviour described in the previous clause. In (16b) pues is stressed and limited by pauses corresponding to commas in the text. It is inserted in the middle of a sentence containing an advice that follows what is described in the previous sentence. These are the features that typically correspond to a consecutive pues.

\subsection{The extended local use of pues}

As shown in section 1, in BCS there exists another pues that is found everywhere in the Basque Autonomous Community and Navarre but particularly inside the Basque-speaking area. This local use was previously illustrated by the examples in (1) that are reproduced below as (17). It was also noticed that this feature was present in the speech of both monolingual Spanish speakers (17a) and, especially, bilingual speakers (17b):

a. $\quad-$ ¿Y aónde vais a ir hoy, pues..., a la tarde?

'- And where are you going then..., in the afternoon?'

(COSER, Luzuriaga AL-0107: 60)

b. Sí, es que ya te digo, pues; mis hermanos estuvieron en guerra cinco meses...

'Yes, I'm telling you in that case; my brothers remained at war five months...'

(COSER, Leitza NA-3214: 13)

This extension and vitality are proved by the fact that this use is recognisable as a typical feature of the variety of Spanish spoken in the Basque Country. Unsurprisingly, this local pues can be found in literary works, for instance in Aramburu's books, to define the speech of Basque characters. The following fragments from one of his novels are good examples of this stylistic strategy: 
(18) a. ...No sabe quién lo sacó. El conductor sería, pues.

'...He doesn't know who took it out. It would have been the driver in that case'

(Patria: 169)

b. $\quad$ - ...ंNo has oído alguna vez las palabras del obispo de nuestra diócesis? Ve tranquila a tu casa, pues.

'- ...Haven't you ever heard the words of the bishop of our diocese?

Go home then and be calm'

(Patria: 303)

c. $\quad$ - Anda, anda, eso no es un deporte.

- ¿Qué es, pues?

- El balonmano es al fútbol lo que el pimpón al tenis.

'- Come on, that is not a real sport.

- What is it then?

- Handball is to football what ping-pong is to tennis'

(Patria: 375)

These examples from written language, however, cannot make us forget that this pues is a typical feature of the spoken register, as can be seen by the examples in (17), all of which transcribed conversations. In all these cases in (1718) we find that pues is a stressed word, an adverb with sentence scope. It is always placed in clause-final position and followed by a clearly audible pause, marked in transcriptions by commas, semicolons or full stop. It is also preceded by a shorter pause, corresponding to a comma in the texts, but this is not always transcribed.

As (17a) and (18c) show, this final pues also appears in wh-interrogative sentences but not in yes-no questions. This former context is regularly selected by Spanish grammars to describe Basque pues. For instance, as we recalled in section 1 , the academic grammar exemplifies it with the sentence ¿Vienes a la playa, pues? 'So, are you going to the beach?' (RAE-ASALE 2009: § 30.13m). And Portolés (1989: 126) also quotes two sentences of this kind when talking about the use of pues in Northern Spain:
a. ¿Adónde iba a ir? Pues [sic]
'Where was he going then?'
b. ¿Qué pasa? Pues [sic]
'What's going on then?'

The high frequency of this specific context for Basque pues contributes to associate to it a distinctive prosody that is in fact that of the ordinary wh-questions with a dislocated final element in Spanish, that is, a falling intonation. Regarding this common but misleading assumption, it is important to remember that this same final pues is also present in affirmative sentences (1b and 17a-b), a type of sentence with a different intonation. Other samples of this frequent interrogative use are the following: 
(20) a. $\quad$ - ... mi madre, por ejemplo, se tiraba toda la mañana, toda la mañana en la cocina, hoy pones la olla y para cuando has ido a trabajar [...] está todo.

- Tienes el microondas, tienes la...

- Es que es, es... [...]

- ¿Cómo tienes, pues?... Sufrido, ¿no? De ayudar a la mujer...

'... my mother, for instance, stayed all morning in the kitchen, nowadays you set the cooker and when you left to work it's all done.

- You have the microwave, you have the...

- It's, it's... [...]

- ¿How did you do then? You suffered, didn't you? Helping your wife...'

(COSER, Aginaga GI-2001-2: 34)

b. $\quad$ - ... y cuando estaba, qué sé yo, pues..., veinte grados o así de caliente, echábamos cuajo, viene con un trapico limpio otra vez. '- ... and when it was hot, well, what do I know..., twenty degrees or so, we put rennet in, it comes again in a clean cloth'

(COSER, Leitza NA 3214: 13)

Finally, this pues which is found in interrogative contexts can also be found as an independent question marker in colloquial questions, corresponding to general Spanish ¿entonces?, ¿y eso? 'so?, so what?...', as in the following text:

(21) Y, bueno, salíamos, paseábamos pues dos kilómetros o tres, y volvía. Y un día me llamó el cura este y me dice: "¿Qué?, tú ¿qué?, tú ¿quién crees que eres?", me dijo. "¿Pues?”. "Ninguna pasea y tú pa pasear un domingo por la tarde con el novio, tú ¿quién crees que eres?"

'And, well, we got out, went for a walk, well, two kilometres or three and I came back. And one day this priest called me and says: "What then? what? who do you think you are?", he told me. "So?", "No girl walks arouns and you're out wandering with your boyfriend, you, who do you think you are?"'.

(COSER, Aulesti BI-4501: 23)

As to the interpretation of this extended use of pues in BCS, the scarce previous descriptions provide few but interesting clues, as we will see. In order to achieve a better understanding of its content and pragmatic value, it is interesting to check its behaviour when used in dialogues. As we could see with the consecutive pues in (8), this Basque pues can track the intervention of a different interlocutor in a conversational exchange or can be connected with previous comments by participants other than the speaker, as in (1a) and (18c). In all these cases it can be substituted by the consecutive adverb entonces in general Spanish in its canonical sentence-initial position, as the following examples, built as alternatives to (1a) and (18c), illustrate:

(22) a. $\quad$ ¿Y entonces, aónde vais a ir hoy..., a la tarde?

'- And where are you going then..., in the afternoon?' 
b. $\quad$ - Anda, anda, eso no es un deporte.

- ¿Qué es, pues?

- El balonmano es al fútbol lo que el pimpón al tenis.

'- Come on, that is not a real sport.

- What is it then?

- Handball is to football what ping-pong is to tennis'

(Patria: 375)

But, contrary to entonces, it can also be used whenever it continues a previous sentence by the same speaker, as in (18a-b). In that case it can be substituted by consecutive and internal pues in the following general Spanish alternatives to $(18 \mathrm{a}-\mathrm{b})$ :

(23) a. ...No sabe quién lo sacó. Sería, pues, conductor.

'...He doesn't know who get it out. It would have been the driver in that case'

b. $\quad$ - ...¿No has oído alguna vez las palabras del obispo de nuestra diócesis? Ve, pues, tranquila a tu casa.

'- ...Haven't you ever heard the words of the bishop of our diocese?

Go home then and be calm'

A similar behaviour is found in Basque examples such as (20a) and (21) where the local pues can be recreated by general Spanish entonces. All these correspondences give way to the hypothesis of a fundamental relation between this BCS pues and the consecutive pues (and entonces) of Standard Peninsular Spanish, something we had previously mentioned (Camus 2012: 232-233).

This relation can also be maintained for the majority of the examples so far provided for BCS, though some of them seem to present further difficulties. First of all, the previous situation that licenses the corresponding expression of a consequence is not explicit and should be deduced from a wider context. This is the case in example (17b) where there is reference to previous discourse. In (17b) ya te digo, 'as I told you', refers to something already mentioned by the speaker (or known to be usually said by her). In (20b) que sé yo, 'what do I know?, I don't really know...' serves to reaffirm well-known ignorance and therefore asks for indulgence towards the information transmitted. This previous common knowledge can be then considered as a good starting point, for a sentence with pues, of a somewhat consecutive or resultative meaning. In that case (24a) and (24b) may be possible paraphrase for (17b) and (20b) respectively:

(24) a. Si es que ya te digo, por tanto...

'Yes, I'm telling you in that case...'

b. $\quad$...y cuando estaba, pues, qué sé yo, veinte grados...

'- ... and when it was hot, I don't really know, twenty degrees or so...'

There are also problems with the interpretation of pues in (25a-b): 
(25) a. Ahora no los tenemos [cerdos], pero ya sabemos engordar, pues. 'We haven't them [pigs] anymore, but we do know how to fatten them up'

(COSER, Gabiria GI-2004: 11)

b. $\quad$ - O sea que el, el, el cuajo natural resulta que hace un queso demasiado fuerte.

- Demasiao fuerte. Bueno, algunos ya le echarán, pues; esos que les gusta beber un poco vino dicen...

'-So natural rennet happens to produce too strong a cheese.

- Too strong. Well, some may put that then; those who like to drink a little bit of wine, as they say'

(COSER, Zarimutz / Aretxabaleta GI-2012: 10)

These two clauses present the positive polarity item of BCS $y a$, a particle that emphasises the truthfulness of the facts reported (Camus 2012: 223-229). This allows us to suggest an interpretation for pues in these contexts slightly different from the one suggested up to this point. Pues in (25) may be just another emphatic element to reinforce statements. This is in fact the description provided, for instance, by ASinEs: "recurso enfático al final del enunciado" 8 ". This emphatic nature has already been described for some other instances of this Basque pues, particularly in interrogative sentences, such as (1a), (18c) or (20a). In this sense it is worth reminding that this reinforcing or phatic use is commonly found for commentating pues in general Spanish ${ }^{9}$. This pragmatic extension in comparison with consecutive pues can be explained considering the greater productivity of Basque pues. There could have been a continuing erosion of the link between cause and effect clauses where this pues is placed.

To summarize what has been said in this section, the local use of pues in BCS is mainly connected with the consecutive adverb pues in Standard Peninsular Spanish. They share some categorial properties such as the stress and phonetic independence. Furthermore, they are related by their semantic and pragmatic role. Both of them establish a basic consecutive interpretation of the clause they belong to with reference to the facts described by the previous clause or deduced from the context. On the contrary, Basque pues is clearly preferred in sentence-final position and belongs to a colloquial and spoken style. Its great productivity could help to account for some other uses where its conversational content has been reduced to a simple phatic function.

\section{Final remarks: exploring the origins of $\mathrm{BCS}$ pues}

One of the most striking elements regarding these extended uses of pues in BCS is the fact that they seem to reappear with very similar features in some other contact varieties in America. This section will be devoted to provide a description

$8 \quad$ 'Emphatic resource at the end of the sentence'.

9 This 'emphatic drift' seems to be the explanation for some of the uses of the Portuguese equivalent pois (Pinto de Lima 2002). 
of these Spanish American uses in order to figure out the plausibility of a relation with the European data.

\subsection{Pues in American and Andean Spanish}

Final position pues is widely found in different areas of South America. Olbertz (2013) claims that this distribution is not at all strange in places such as Caracas, Quito or Lima and has been abundantly documented in 19th century texts from Chile or Venezuela. On the contrary, final position pues seems to be inexistent in Río de la Plata Spanish.

From now on, we will turn our attention to those American varieties that show the most consistent and best described use of this final position pues, the Andean Spanish. In fact, this use is documented since the final decades of the past century in Andean countries (Hardmann-de-Bautista 1982; Zavala 2006; Olbertz 2013 among many others). It seems to be used in Peruvian Spanish in all socio-cultural backgrounds. It is also frequent in the rural Spanish of the Ecuadorian Highlands. It is also documented in Bolivia, where it does not seem to be so widely used.

This Andean pues, as described by Zavala (2006) or Olbertz (2013), is very often pronounced with a significant phonetic reduction: pe, pes, pos, ps. Despite this feature, it is always an adverb that is placed at the end of its clause and is therefore surrounded by pauses. According to Olbertz (2013: § 3), the interpretation of this Andean use, at least the Ecuadorian Highland version, includes basically two main meanings.

The first is a basic conclusive reading that serves to provide a final outcome or conclusion to a previous linguistic interaction of another participant (26a), but also of the same person, as shown in the following dialogues corresponding to examples (6) and (7) from Olbertz (2013): ${ }^{10}$

a. [talking about Germany during WW2]

- Ganó a Inglaterra.

- No ganó, no.

- Sí ganó.

- No, como nunca entraron en Inglaterra.

- Sí ganó a Francia.

- A Francia sí, a Holanda también.

- Pero a dos..., a dos naciones ganó pues.

'- They beat England.

- No, they didn't.

- Yes they did.

- No, as long as they didn't invade England.

- They did beat France.

- They did beat France and Netherlands as well.

- But two..., so they beat two nations'

$(\mathrm{CdS}$ E 2b)

10 Olbertz selects these examples form the so called Corpus de Salcedo, therefore quoted CdS in her work, a corpus of oral data recorded by Peter Muysken in 1978 in the town of Salcedo (Ecuador). 
b. - ¿Y cómo juegas? Cuenta. ¿Cómo es?

- No, así en la cancha nomás jugando con las, uno el tres, otro... el tres... al otro lado, así jugando nomás.

- ¿Y qué se hace cuando se juega? ¿Cómo se juega?

- Eh, apostando con la plata. El que se gana se lleva la plata pues.

'- And how do you play? Tell. How is it?

- No, just playing this way in the field with the..., one number three, another... number three... to the other side, just playing this way.

- And what do you do when you play? How is it played?

- Eh, betting with money. So the winner takes the money'

(CdS Q 3a)

As claimed by Olbertz, this conclusive use is often accompanied by an emphatic attitude that could be interpreted as a desire to be supported by the rest of the participants ('you see I am right, don't you?').

The other possible reading of this pues is emphatic, according to Olbertz (2013). It is sometimes combined with the conclusive one, as in (26) or, less evidently, in (27), where the presence of an imperative (ponga 'switch on') contributes to the reinforcement meaning (Olbertz 2013: example 8):

- ¿Por qué no prende radio? ¿Radio es?

- Vamos a poner, ¿sí quiere música usted?

- Sí, iponga pues!

'-Why don't you switch on the radio? Is it a radio?

- Let's switch it on. You want music, yes?

- Yes, so switch it on'

(CdS M1 8b)

In other cases, this emphatic reading is prevalent, as in the example (10) of Olbertz 2013, here transcribed as (28):

(28) - ¿Por qué no le gusta el trago?

- Porque no, bonita. Eso hace hablar cambiado, hace chumar, hace hablar cosas que no nos interesan, estar echado ahí.

- Pero sí dice[n] que ha chumado, pues.

- ¿Ónde pues?

- Allá en el bautizo, en el traslado.

'- Why don't you like the booze?

- Just because, beauty. It makes you talk strange, makes you get drunk, makes you tell things that we aren't interested in, makes you lie down over there.

- But they say you actually drank.

- Where so?

- Over there at the christening, during the walk'

(CdS M1 6b) 
The first pues in (28) (pero sí dicen que ha chumado, pues, 'but they say you actually drank') is clearly assertive and therefore emphatic; the speaker is reinforcing her statement, which contrasts with the content of previous intervention of her partner. But the second pues (¿ónde pues?, 'where so?') is again a combination of conclusive and emphatic use. It shows a consecutive or conclusive relation with the previous intervention and the insistence on the interrogative force of the speech act.

The previous description of the features and meaning of pues in Ecuador offers some similarities with the description we gave for BCS pues in section 3 . Both of them belong to an informal and colloquial register. They are both placed between pauses and in final position. Finally, they seem to establish a cause-effect relation between a precedent clause and the one with pues. Both of them seem to add some emphasis to this relation, therefore a conclusive interpretation, as suggested by Olbertz (2013), seems to be plausible. ${ }^{11}$

\subsection{Exploring the relation between Andean Spanish and Basque Country Spanish}

This coincidence between these two contact varieties of Spanish, Andean Spanish and BCS, with respect to the extended uses of the connective pues described so far, is in fact part of a number of shared features. The pronominal clitic system in both dialects is another one, probably the best known and studied (FernándezOrdóñez 1999). There are also interesting similarities in the way both varieties incorporate some evidential contents through different grammatical categories that are actually absent in Standard Spanish (Camus 2012). These coincidences can be explained as a consequence of different processes of change and syntactic convergence that are triggered by a particularly intense and long-lasting contact situation.

In the case of pues a tentative search for a common explanation based on contact must inevitably consider the possibility of an external cause via transfer from the substratum / adstratum languages, that is, Basque in the case of BCS and Quechua /Quichua and Aimara in the case of Andean Spanish.

As for the Basque case, evidence of this external explanation can be provided by the presence of a Basque particle that is very similar BCS pues. It is the particle $b a(d a)^{12}$, a very plausible candidate for transfer since its syntactic distribution and its content match the corresponding properties of the extended use of pues in BCS. This $b a(d a)$ presents a final position distribution and is usually recreated in Spanish as entonces or pues, the consecutive adverbs that replicate best the conclusive content of the Basque particle (Hualde \& Ortiz de Urbina 2003: 538; Oñederra 2004: 1112; Camus 2012: 232). As shown in the following examples, the contexts for $b a(d a)$ are the same as for BCS pues, even in interrogative sentences:

11 Contrary to the so-called conclusive uses of pues bien described by Fuentes (1993: 210-212), this Andean pues does not include a change of perspective or point of view. They are in fact closer to the commentating uses of a recapitulative type considered by Portolés (2016: 293-294).

12 The complete form of this word is actually bada, but it is generally reduced in informal language to $b a$. 
(29) a. Negua etorri da; berokia atera behar dugu, $b a(d a)$.

'Winter has come; we've got to take out the coat in that case'

b. Nor etorri da, $b a(d a)$ ?

'Who has come then?'

Contrary to this salient coincidence between Basque and BCS, the case for a transfer from substratum/adstratum languages in Andean Spanish is not so clear, even if this possibility has been repeatedly defended in most of the works dedicated to this topic, particularly by the Peruvian linguist Virginia Zavala (see, for instance, Zavala 2009 and the works cited in Olbertz 2013). The most likely candidate to be paralleled by Andean pues could be the Peruvian Quechua and Ecuadorean Quichua particle -mi. This particle belongs to the so-called group of independent affixes that can be attached to any category of words. It is clearly connected to the expression of focus and has also some evidential contents together with assertive and emphatic functions. Although Olbertz (2013: section 4) raises serious objections to a complete correspondence between Andean pues and this - $m i$ particle, it may still be considered a plausible starting point if we are looking after an external explanation for the extended uses of pues in the Andean varieties of Spanish.

Besides this external causation for the extended uses of pues, Olbertz (2013: section 5) presents a good case for an internal explanation based on older uses of pues in Classical Spanish. ${ }^{13}$ This hypothesis is actually suitable not only for Andean Spanish but also for BCS, as we shall see. Following Iglesias (2000), Olbertz traces the consecutive uses of pues to the medieval texts where this adverb is extended from its basic temporal content ( $<$ lat. POST 'afterwards') to a causal meaning - hence the current causal conjunction - and a connective that indicates mainly posterity. As soon as around 1500 we can begin to find examples of pues in internal position (30a) or even in final position with short clauses (30b) that can be considered as precedents of the current consecutive use we described in section $2.4:^{14}$

(30) a. Toma, pues, agora tres consejos míos, [...]

'So take from me now three pieces of advice'

(1529-1531; Fray A. de Guevara, Reloj de príncipes;

CORDE, in Olbertz 2013: ex. 37).

b. Pandulfo: ¿Has de abrir allá, o tienes algún gayón que me ha tomado la posada?

Palana: Aguardá que ya voy.

Pandulfo: Abre, pues.

'Pandulfo: Are you going to open or have a pimp taken my lodge?

13 The Classical Spanish data selected by Olbertz correspond to the Corpus de referencia diacrónico del español (CORDE) and Mark Davis's Corpus del español (CdE).

14 Iglesias and Olbertz call this use conclusive, as we saw in relation to the Andean pues. It is important to notice that Porcar (2003) had classified this conclusive use as a type of the consecutive one. In her opinion this conclusive meaning is only developed in Medieval Spanish by those discourse markers with consecutive interpretation. Pues would be precisely among them. 
Palana: Wait, I'm coming.

Pandulfo: So open up'

(1522; Feliciano de Silva, Segunda Celestina; CdE, in

Olbertz 2013: ex.38)

This consecutive pues, as Olbertz (2013: fn 25) points out, started to become more and more unusual in European Spanish texts during the 18th century, thus giving way to the formal consecutive pues of current written Spanish. Olbertz (2013) concludes then that the final pues of Andean Spanish (and in our opinion also BCS pues) could simply be a case of internal development of the old consecutive use documented in Classical Spanish.

There are however more possibilities to explain the basic coincidence of these modern developments of pues in Contact Spanish. Their advantage is, as we shall see, the fact that they offer a scenario that accounts for the external or contact hypothesis as well as for the internal or historical one. This synthetic view relies mainly on two ideas that are commonly found in Contact Linguistics, as will be explained in the following paragraphs.

First of all, there exists a general agreement about the inhibiting and blocking effects that contact situations have on language change. It has often been observed that, in case of intense contact, old structures tend to be retained after their disappearance or modification in more innovative varieties. That is precisely what Blas Arroyo (2007) or Enrique-Arias (2006, 2012, 2014) have repeatedly noted in the case of the Spanish spoken in Castellón or Majorca respectively, areas where an intense contact with Catalan exists since the 18th century. In both cases, for instance, the Spanish synthetic future is preferred over the periphrastic one, an innovative form that on the contrary seems to be predominant in the rest of Peninsular Spanish.

Also language contact situations tend to give birth to unstable varieties that often bear new possibilities for existing structures. These new developments are generally favoured by similar patterns in the substratum language thus acting as a strong catalyst of change (Palacios 2013; Palacios \& Pfänder 2014). This linguistic change induced by contact has been considered a case of grammaticalization of previous features by means of the identification and assimilation of similar existing structures in the contact language (Matras 2011). ${ }^{15}$

With these two conditions in mind, we could look at the evolution of pues in Basque and Andean Spanish in a more comprehensive way and reformulate previous explanations. These extended uses of pues could then be considered local developments of the consecutive pues of Classical Spanish in a context of intense contact. The new uses would have been guided by the presence of similar structures and lexical items in the surrounding languages. That would help to understand the connection with the old pues as well as the relation with substratum languages that are found in the new extended local use of this connective.

15 On the relationship between change in contact situations and grammaticalization, see Garachana (2015). 


\section{Concluding remarks}

As stated in the first section, this work intends to sketch the preliminary guidelines for the description and analysis of what we have called the extended use of the connective pues in BCS. Its main distributional features and basic connection to Standard Spanish consecutive pues have been therefore established in sections 2 and 3. At this point, it is still necessary to keep searching for those uses that seem to be more distant from this content and are reminiscent of the commentating and continuative uses in general Spanish. And, above all, there is still pending work to understand the proper relation of this BCS pues with similar connectives in Basque. This issue leads directly to the other crucial topic, that is, the role played either by the contact languages or by older uses of pues in Classical Spanish in the development of extended uses of this connective, not only in Basque but also in American Spanish varieties, particularly in Andean Spanish. This clearly stands as an open research topic and needs further efforts to be understood better.

\section{References}

Blas Arroyo, José Luis. 2007. "El contacto de lenguas como factor de retención en procesos de variación y cambio lingüístico. Datos sobre el español en una comunidad bilingüe peninsular". Spanish in Context 4/2: 263-291.

Briz, Antonio \& Salvador Pons \& José Portolés (eds.). Diccionario de partículas discursivas del español (en línea). http://www.dpde.es [31/10/2017]. Quoted as DPDE.

Camus, Bruno. 2012. "Modo, evidencialidad y modalidad en el castellano del País Vasco". In Camus, B. \& S. Gómez Seibane (eds.), El castellano del País Vasco, 215-233. Bilbao: UPV.

Camus, Bruno \& Sara Gómez Seibane. 2012. "Introducción: El castellano del País Vasco". In Camus, B. \& S. Gómez Seibane (eds.), El castellano del País Vasco, 1-17. Bilbao: UPV.

Dorta Luis, Josefina \& M $^{\mathrm{a}}$ Noemí Domínguez García. 2001. "Polifuncionalidad discursiva y comportamiento prosódico prototípico del marcador pues". Español actual 75, 43-53.

Enrique-Arias, Andrés. 2006. "Spanish / Catalan Contact in Historical Perspective: 18th Century Documents from Majorca". In D. Heap \& E. Pato \& C. Gurski (eds.), New Perspectives in Iberian Dialectology / Nouvelles perspectives en dialectologie ibérique, 1-11. London: University of Western Ontario.

Enrique-Arias, Andrés. 2012. "El contacto de lenguas como inhibidor del cambio lingüístico: castellano y catalán en Mallorca". In E. Montero Cartelle (ed.), Actas del VIII Congreso Internacional de Historia de la Lengua Española, 569-580. Madrid: Arco Libros.

Enrique-Arias, Andrés. 2014. "Efectos del contacto de lenguas en el castellano de Mallorca: una perspectiva histórica". In A. Enrique-Arias et alii (eds.), Perspectives in the Study of Spanish Language Variation Papers in Honor of Carmen Silva-Corvalán, Anexo 72 Verba, 271-297. Santiago: 
Universidade de Santiago.

Fernández-Ordóñez, Inés. 1999. "Leísmo, laísmo y loísmo”. In I. Bosque \& V. Demonte (dirs.), Gramática descriptiva de la lengua española, 1317-1397. Madrid: Espasa.

Fuentes, Catalina. 1993. "Comportamiento discursivo de bueno, bien, pues bien", Estudios Lingüísticos de la Universidad de Alicante 9, 205-221.

Fuentes, Catalina. 2009. Diccionario de conectores y operadores del español. Madrid: Arco Libros.

Garachana, Mar. 2015. “Teoría de la gramaticalización. Estado de la cuestión”. In J. M. García Martín (dir.), Actas del IX Congreso Internacional de Historia de la Lengua Española (Cádiz, 2012), vol. 1, 331-360. Madrid/Fráncfort: Iberoamericana.

Garcés, Ma Pilar. 1992. "El operador discursivo pues en el español hablado". Romanistisches Jahrbuch 43, 261-276.

Hardman-de-Bautista, Martha J. 1982. "The mutual influence of Spanish and the Andean languages". Word, 33:1-2, 143-157.

Herrero Ruiz de Loizaga, Javier. 1998. "Las oraciones causales con pues y pues que en el siglo XV”. In C. García Turza \& F. González Bachiller (eds.), Actas del IV Congreso internacional de historia de la lengua española, vol. 1, 523-531. Logroño: Universidad de la Rioja.

Hualde, José Ignacio \& Jon Ortiz de Urbina. 2003. A Grammar of Basque. Berlin: Mouton de Gruyter.

Iglesias, Silvia. 2000. "La evolución histórica de pues como marcador de discurso hasta el siglo XV". Boletín de la Real Academia Española 80: 59-102.

Martín Zorraquino, M ${ }^{\mathrm{a}}$ Antonia \& José Portolés. 1999. "Los marcadores de discurso". In I. Bosque \& V. Demonte (dirs.), Gramática descriptiva de la lengua española, 4051-5213. Madrid: Espasa.

Matras, Yaron. 2011. "Grammaticalization and language contact". In H. Narrog \& B. Heine (eds.), The Oxford Handbook of Grammaticalization, 279-290. Oxford: Oxford University Press.

Olbertz, Hella. 2013. “'Pues' en el español rural de la sierra ecuatoriana: ¿interferencia del quichua?". In C. Felbeck \& A. Klump \& J. Kramer (eds.), America Romana: Perspektiven transarealer Vernetzungen, 179204. Frankfurt am Main: Peter Lang.

Oñederra, Ma Lourdes. 2004. "El español en contacto con otras lenguas: españolvasco”. In R. Cano (coord.), Historia de la Lengua Española, 1103-1115. Barcelona: Ariel.

Palacios, Azucena. 2013. "Contact-induced change and internal evolution: Spanish in contact with Amerindian Languages". In I. Léglise \& C. Chamoreau (eds.), The Interplay of Variation and Change in Contact Settings. Morphosyntactic Studies, 165-198. Amsterdam/Philadelphia: John Benjamins.

Palacios, Azucena \& Stefan Pfänder. 2014. "Similarity effects in language contact: Taking the speakers' perceptions of congruence seriously". In J. Besters-Dilger \& C. Dermarkar \& S. Pfänder \& A. Rabus (eds.), Congruence in Contact-Induced Language Change. Language Families, Typological Resemblance and Perceived Similarity, 219-238. Berlin/Boston: De Gruyter. 
Pinto de Lima, José. 2002. "Grammaticalization, subjectification and the origin of phatic markers". In I. Wischer \& G. Diewald (eds.), New reflections on grammaticalization, 363-378. Amsterdam: Benjamins.

Porcar, Margarita. 2003. "Sobre los marcadores con función conclusiva. Análisis de sus empleos discursivos (ss. XIII- XVI)". Moenia 9: 199-221.

Portolés, José. 1989. "El conector argumentativo pues". Dicenda 8: 117-133.

Portolés, José. 1993. "La distinción entre los conectores y otros marcadores del discurso". Verba 20: 141-170.

Portolés, José. 2001. Marcadores del discurso. Second Edition. Barcelona: Ariel.

Portolés, José. 2016. "Marcadores del discurso". In J. Gutiérrez Rexach (ed.), Enciclopedia de Lingüística Hispánica, vol. 1, 689-699. London: Routledge.

RAE - ASALE. 2009. Nueva gramática de la lengua española. Madrid: Espasa.

Stenström, Anna-Brita. 2006a. "The Spanish discourse markers o sea and pues and their English correspondences". In K. Aijmer, K. \& A. M. SimonVandenbergen (eds.), Pragmatic Markers in Contrast, 155-172. Amsterdam: Elsevier.

Stenström, Anna-Brita, 2006b. "The Spanish pragmatic marker pues and its English equivalents". In A. Renouf \& A. Kehoe (eds.), The Changing Face of Corpus Linguistics, 263-281. Amsterdam/NewYork: Rodopi.

Zavala, Virginia. 2006. "Transferencia de funciones evidenciales del quechua: El rol de pues como marcador discursivo en el español andino". Lexis 30/1: 55-82.

\section{Corpora and cited texts}

ASinEs = Atlas Sintáctico del Español [online]. http://asines.org. [December 11th 2017].

CorpusPV = Camus, Bruno \& Sara Gómez Seibane. 2012-. Corpus de castellano del País Vasco. Work in Progress.

COSER = Fernández-Ordóñez, Inés (dir.). 2005-. Corpus oral y sonoro del español rural. Universidad Autónoma de Madrid. http://www.corpusrural.es.

Patria $=$ Aramburu, Fernando. 2016. Patria. EPub edition, Barcelona: Tusquets.

Val.Es.Co. 2.0 = Cabedo, Adrián \& Pons, Salvador (eds.). Corpus Val.Es.Co 2.0. http://www.valesco.es. 